\title{
Betegségismeret 2-es típusú diabetesszel élők körében: a Diabetes Knowledge Test magyar nyelvü validálása
}

\author{
Papp-Zipernovszky Orsolya dr. ${ }^{1}$ - Klinovszky Andrea ${ }^{2}$ - Buzás Norbert dr. ${ }^{2}$ \\ ${ }^{1}$ Szegedi Tudományegyetem, Bölcsészettudományi Kar, Pszichológiai Intézet, Szeged \\ ${ }^{2}$ Szegedi Tudományegyetem, Általános Orvostudományi Kar, Egészség-gazdaságtani Intézet, Szeged
}

Bevezetés: Magyarországon a KSH szerint több mint 1 millió ismert cukorbeteg él. A diabetes karbantartásához elengedhetetlen a betegek tudásának, készségeinek és önhatékonyságának növelése és fenntartása. A legelterjedtebb diabetes-betegségismeretteszt a 23 kérdéses Michigan Diabetes Knowledge Test. Első 14 tétele általános tudást mér, például az ételek tápanyagtartalmával és a vércukorszint-változás okaival kapcsolatban. További 9 kérdése az inzulinhasználatról szól.

Célkitüzés: Célunk ennek a tesztnek a magyar nyelvü validálása, valamint összefüggéseinek vizsgálata szociodemográfiai és betegségváltozókkal.

Módszer: Keresztmetszeti kérdőíves kutatásunkban a tesztcsomagot 129, inzulint használó, 2-es típusú diabeteses beteg töltötte ki (84 nő, átlagéletkor: 59,67; szórás: 12,6) elsősorban online, betegszervezeteken keresztül.

Eredmények: A betegségismeret-teszt belső konzisztenciája 0,603, ami elfogadható érték. A 23 kérdés helyes kitöltési arányának átlaga 81,66\%, ami az amerikai arányokhoz hasonló, más kutatások speciális csoportjaihoz képest azonban kifejezetten magas érték. A válaszadók a ketoacidosis fogalmát, az egyes ételek tápanyag-összetevőit és az elfogyasztott ételek vércukorszintre gyakorolt hatását illető kérdésekre tudták a választ a legkevésbé. A magyar teszt a szakirodalomnak megfelelő gyenge, negatív irányú összefüggésben áll az életkorral, és pozitív a kapcsolata az inzulinhasználat hosszával, valamint a napi vércukorszintmérés és inzulinbeadás számával. A betegségismeretet függetlenül egyedül a napi vércukorszintmérés mennyisége jósolta meg. A teszt konvergens validitását mutatja gyenge, de szignifikáns összefüggése az egészségértést mérő Brief Health Literacy Screening kérdésekkel.

Következtetés: A magyar nyelvú Diabetes Betegségismeret Teszt alkalmas a diabetesszel élők tudásszintjének felmérésére. Mintánkban a betegségismeret magas szintje az inzulint használók megfelelő edukációjával függhet össze. Ugyanakkor eredményeink felhívják a figyelmet a betegek diétával kapcsolatos magasabb szintű tudásának szükségességére.

Orv Hetil. 2021; 162(22): 870-877.

Kulcsszavak: egészségértés, betegségismeret, validálás, Diabetes Betegségismeret Teszt

\section{Illness knowledge of type 2 diabetes patients: the Hungarian validation of Diabetes Knowledge Test}

Introduction: According to the Hungarian Central Statistical Office, more than 1 million diabetic patients live in Hungary. It is essential to enhance and sustain the knowledge, skills and self-efficacy of patients. The most widely used measurement of illness knowledge is the 23-item Michigan Diabetes Knowledge Test (DKT). Its first 14 items measure general knowledge: the nutritional value of food, and causes of change in blood glucose level. Its further 9 items are about insulin usage.

Objective: To examine the reliability and the validity of the Hungarian version of DKT2 as well as its association with sociodemographic and illness-related variables.

Methods: In our cross-sectional quantitative study, 129 patients ( 84 women, mean age: $59.67 ; \mathrm{SD}=12.6$ ) diagnosed with type 2 diabetes mellitus using insulin therapy filled in a questionnaire online.

Results: The $\alpha$ coefficient for the test is 0.603 , which is acceptable. The mean of the correct answer rate is $81.66 \%$, which resembles the American results, but it is higher than that of other specific groups. Problem areas for our patients included interpreting ketoacidosis, the nutritional value of foods and the effect of foods on blood glucose 
level. The score of the Hungarian test - in accordance with the literature - correlates negatively with age, positively with the year of insulin-usage and with the number of daily insulin intake and of blood glucose measurement. Illness knowledge was independently predicted only by the number of daily blood glucose measurement. The convergent validity of the Hungarian test is supported by its weak but significant association with Brief Health Literacy Screen questions.

Conclusion: The Hungarian DKT2 properly measures the illness knowledge of diabetic patients. Their high level of knowledge can be traced back to the speciality of the subjects as well as to the overall education of insulin users. Nevertheless, our results draw attention to the necessity of enhancing the level of dietetic knowledge of patients.

Keywords: health literacy, illness knowledge, validity, Diabetes Knowledge Test

Papp-Zipernovszky O, Klinovszky A, Buzás N. [Illness knowledge of type 2 diabetes patients: the Hungarian validation of Diabetes Knowledge Test]. Orv Hetil. 2020; 162(22): 870-877.

(Beérkezett: 2020. október 1.; elfogadva: 2020. november 1.)

\section{Rövidítések}

BHLS $=($ Brief Health Literacy Screen $)$ az egészségértés gyors előszürése; DKN scales $=($ Diabetes Knowledge scales $)$ a diabetesszel kapcsolatos ismereteket értékelő skálák; DKQ = (Diabetes Knowledge Questionnaire) a diabetesszel kapcsolatos ismereteket mérő kérdőív; DKT2 = (Diabetes Knowledge Test 2) Diabetes Betegségismeret Teszt; DPKT $=($ Diabetes Patient Knowledge Test) betegségismeretet felmérő teszt diabetesesek számára; EFOP = Emberi Erőforrás Fejlesztési Operatív Program; HbAlc = hemoglobin-A-lc; KSH = Központi Statisztikai Hivatal; SD = standard deviáció; SZTE ÁOK = Szegedi Tudományegyetem, Általános Orvostudományi Kar

Az International Diabetes Federation 2019. évi adatai 463 millió, diabetesszel élő felnőttről számolnak be világszerte; becslésük szerint ez a szám 25 éven belül 700 millióra emelkedhet [1]. Magyarországon a KSH 2017. évi összesítése szerint több mint 1 millió ismert cukorbeteg él.

A 2-es típusú diabetes ellátása az esetek többségében a gyógyszeres terápián túl komplex életmód-terápiát is igényel, amely magában foglalja speciális diéta követését és a rendszeres testmozgást. Ennek megfelelően a beteg önmaga is aktív részese a kezelésnek, így tudásának, készségeinek és önhatékonyságának szintje alapvetően határozza meg betegsége karbantartását [2]. Al-Qazazés $m$ tsai [3] a diabeteskezelés és az egészségügyi kimenetelek javítása szempontjából is az öngondoskodás edukációját tartják a legfontosabbnak.

Vizsgálatunkban a betegek tudását mérő, klinikai gyakorlatban is széles körben alkalmazott Diabetes Betegségismeret Teszt magyar validálását végeztük el.

\section{Az egészségértés és a betegségismeret szerepe a diabetes ellátásában}

Az egészségértés „... az egészséggel kapcsolatos alapvető információk és szolgáltatások elérésének, értelmezésének és megértésének képessége, valamint ezen informá- ciók és szolgáltatások felhasználásának kompetenciája az egészség fejlesztése érdekében" [4]. Komplex kognitív, motivációs és szociális készségeket magában foglaló fogalomról van szó, amely erős, pozitív kapcsolatban áll a mortalitással [5], és jobban képes megjósolni az egészségi állapotot, mint az életkor, a jövedelem, a foglalkoztatási státusz, az iskolázottság vagy a faji, etnikai csoporthoz való tartozás [6]. Schillinger [7] krónikus betegséggel élők (diabetes, asztma, magas vérnyomás) esetében foglalta össze gyakorlati példákon keresztül az alacsony egészségértés jeleit és következményeit: kevésbé értik az állapotukat és annak kezelését, kevésbé tudják megnevezni gyógyszereiket és leírni, hogy mire kapják azokat, gyakrabban vannak olyan hiedelmeik, amelyek az adherenciát akadályozzák. Gyakran olvassák félre még az egyszerúbb betegtájékoztatókat is. Emellett nehézségeik lehetnek a szóbeli kommunikáció során és az egészségügyi kockázatok felmérésekor is.

Szociodemográfiai szempontból az alacsonyabb egészségértésû cukorbetegek idősebbek, nők, alacsonyabb iskolai végzettségưek, és régebb óta élnek együtt a betegséggel [7]. Fransen és kutatócsoportja [8] több empirikus tanulmányt elemzett diabetesesek egészségértésével és önmenedzselési szokásaival kapcsolatban. Következtetésük szerint a sikeres terápiához a betegnek nemcsak kellő motiváltsággal kell rendelkeznie, hanem fejlett önhatékonysággal és magas egészségértési szinttel is. Az eddigi legátfogóbb metaelemzést diabetesesek egészségértése és együttjárásai, következményei között Al Sayah és mtsai [9] végezték. Ebben konzisztens kapcsolatot az egészségértés és a szövődmények kialakulása között mutattak ki.

A betegcsoportok egészségértés-vizsgálata gyakran tartalmaz a betegségról (tünetei, progressziója) és kezeléséről való tudást felmérő kérdéseket. Az egészségértés és a betegségről való tudás (betegségismeret) összefüggése Al Sayah és mtsai [9] metaelemzésében pozitív irányú és konzisztens volt. A páciensek betegségismerete további tudományos vizsgálatokban összefüggött a felnőtt betegek korával (negatív irányban [10]), önhaté- 
konyság-érzetével [11], alacsony szintje negatív befolyással bírt az egészségi állapotra (például a metabolikus kontrollra [9]) és a terápiás adherencia mértékére [12].

\section{Diabetes-tudástesztek}

Az 1980-as évek óta készülnek betegségismeretet felmérô tesztek diabetesesek számára (Diabetes Patient Knowledge Test [DPKT] [13]; Diabetes Knowledge [DKN] scales [10]; Diabetes Knowledge Questionnaire [DKQ] [11]). Az „alapismeretek” között megtalálhatók a glikémiás állapot felborulásának okai, tünetei és kezelése, a magas szénhidráttartalmú ételek azonosítása, a cukorbetegség lefolyása, kezelésének célkitűzései, a vércukor mérése és a betegség komplikációinak felismerése. A DPKT külön kérdéscsoportot szentel az inzulinmenedzsmentnek, a DKQ-ban pedig megjelenik a cukorbetegség típusainak ismerete és az önmenedzselési készségek felmérése is (ez utóbbit méri serdülőknél magyar nyelven a Diabetes Adherencia Kérdőív [14]).

A legelterjedtebb betegségismeret-teszt a Michigan Diabetes Knowledge Test [15], melynek átdolgozott változatát 2016-ban publikálták [16]. Széles körü használata (több mint tíz nyelvre fordították le, Európában például portugál, norvég és szlovén, illetve több arab és afrikai nyelvre, valamint malájra is) és a kutatási eredmények elérhetősége miatt mi is ennek a magyar nyelvú validálása mellett döntöttünk.

\section{A DKT2 és összefüggései}

A teszt első változatát 1998-ban publikálta a Michigan Diabetes Research and Training Center, diabetes-szakértők bevonásával [15]. A 23 kérdés első 14 kérdése mindkét típusú diabetesszel élő számára releváns, általános tudás felmérésére vonatkozik. Tartalmaz állításokat az ételek tápanyagtartalmával, a HbAlc-érték jelentésével, a vércukorszint mérésével, a vércukorszint-változás okaival és kezelésével, valamint a szövődmények felismerésével kapcsolatban. A további 9 kérdés az inzulinhasználatról szól. A teljes teszt kitöltése kb. 15 percet vesz igénybe, és 6. osztályos szövegértési szintre tervezték, elsősorban klinikai kutatások számára, nem specifikus gondozási kérdések megválaszolására [15].

2016-ban az eredeti tesztet átdolgozták (13 tételt módosítottak) az újabb diabetesgondozási és -oktatási iránymutatók figyelembevételével [16] - mi ezt a változatot validáltuk Joseph T. Fitzgerald írásos engedélyével. Az általános teszt megbízhatósága 0,77, az inzulinalskáláé pedig 0,84 - mindkét érték a kiváló megbízhatóság mutatója. A 23 tételre a teszt megalkotói nem közöltek reliabilitásértékeket. A betegségismeret az iskolai végzettséggel mutatott összefüggést (a gimnáziumi érettségi vagy az alatti végzettségűek pontszáma szignifikánsan alacsonyabb volt), emellett a diabetes típusával (az l-es típusú betegek pontszáma magasabb volt), a kezelés típusával (magasabb pontszáma volt a csak inzulint hasz- nálóknak, mint az inzulin és gyógyszer kombinációjának) és a diabetesoktatással [16]. A teszt más nyelveken való validálása során alacsonyabb pontszámot értek el azok, akik idősebbek, és alacsonyabb a családi összjövedelmük [17]. A betegségváltozóknál az alacsonyabb szintű tudás a rövidebb diabetes- és inzulinhasználati időtartammal, a kevésbé gyakori inzulininjekciózással és otthoni vércukorszintméréssel függött össze [17].

2018-ban szaúd-arábiai mintán Zowgar és mtsai [18] - a funkcionális egészségértés mérésében gyakori - inadekvát, marginális és adekvát övezeteket állítottak fel a cukorbetegség-ismeret mértékének jelzésére. A DKT2pontszám 1 és 11 között alacsony, 12 és 18 között átlagos, 19 és 23 között pedig magas cukorbetegség-ismeretet jelez. A sávos felosztás segíti a teszt klinikai alkalmazását, a betegedukáció szintjének illesztését.

\section{Módszer}

\section{Résztvevők}

Az adatgyüjtés 2019. november és 2020. augusztus között történt elsősorban online, a teszt linkjének diabetesszervezetekhez és a közösségi médiában zárt diabetescsoportokhoz történő eljuttatásával. (A kérdőív 2016. évi átdolgozásakor szintén részben online mintán történt az adatfelvétel [16].) Ezt egészítettük ki kiképzett tesztfelvevők ismeretségi körében, háziorvosoknál és a Szegedi Klinikán személyes adatfelvétellel. A végleges mintába 129, 2-es típusú diabeteses személy adatai kerültek be ( 84 nő, átlagéletkor: 59,67; szórás: 12,6), akik legalább fél éve használnak inzulint, 18 év felettiek, és magyar az anyanyelvük. A kutatást a Tudományos Kutatásetikai Bizottság engedélyezte (25866-2/2019/ EKU).

\section{Vizsgálati eszközök}

A kutatás elsődleges célja az EFOP-3.6.1-16-201600008. számú alprojekt keretében a közös értékteremtés-modell adaptálása volt a hazai gyógyszerfejlesztési folyamatra - inzulint használó diabetesesek esetében. Ennek egyik szakaszában kérdőíven felmértük a betegek inzulinhasználattal kapcsolatos élményeit, egészségértését és elvárásait, valamint az új technológiákkal szembeni hajlandóságukat. Az összeállított tesztbattéria az informált beleegyezésen, a demográfiai, valamint betegségjellemzőkön kívül 7, magyar nyelvre fordított vagy validált kérdőívet, az inzulinhasználattal kapcsolatos, általunk szerkesztett érzéslistát és szemantikus differenciálskálát tartalmazott. A jelen tanulmányban nemzetközileg is a leggyakrabban használt, klinikai környezetben elterjedt DKT2-kérdőív [16] magyar adaptációját mutatjuk be (a teszt magyar változatát az 1 . melléklet tartalmazza) a demográfiai és betegségváltozókkal, valamint konvergens validitásként az önjellemző, előszűrésre kifejlesztett egészségértés-kérdésekkel, a Brief Health Literacy 
1. melléklet |A magyar nyelvű Diabetes Betegségismeret Teszt (DKT2) kérdései. A helyes választ * jelöli

\begin{tabular}{|c|c|}
\hline Általános kérdések & Inzulinhasználati kérdések \\
\hline 1. A cukorbetegek étrendje: & 15. A ketoacidosis tünetei közé tartozik: \\
\hline a. ahogyan a legtöbb magyar ember étkezik* & a. reszketés \\
\hline b. egy egészséges étrend a legtöbb ember számára & b. izzadás \\
\hline c. a legtöbb ember számára túl sok szénhidrátot tartalmaz & c. hányás* \\
\hline d. a legtöbb ember számára túl sok fehérjét tartalmaz & d. alacsony vércukorszint \\
\hline 2. Az alábbiak közül melyiknek van a legmagasabb szénhidráttartalma? & 16. Amennyiben egy cukorbeteg influenzás: \\
\hline a. Sült csirke & a. kevesebb inzulint kell bevinnie \\
\hline b. Ementáli sajt & b. kevesebb folyadékot kell innia \\
\hline c. Sült krumpli & c. több fehérjét kell ennie \\
\hline d. Mogyorókrém* & d. gyakrabban kell mérnie a vércukorszintjét* \\
\hline 3. Az alábbiak közül melyiknek a legmagasabb a zsírtartalma? & 17. Amennyiben gyors hatású inzulint vitt be, vércukorszintje nagy valószinü- \\
\hline a. Alacsony zsírtartalmú $(1,5 \%)$ tej* & séggel csökkeni fog: \\
\hline b. Narancslé & a. kevesebb mint 2 órán belül* \\
\hline c. Tarkabab & b. 3-5 órán belül \\
\hline \multirow[t]{2}{*}{ d. Méz } & c. 6-12 órán belül \\
\hline & d. több mint 13 órán belül \\
\hline $\begin{array}{l}\text { 4. Az alábbiak közül melyik ételt „sabad bármikor enni”? } \\
\text { a. Bármilyen, nem édesített étel }\end{array}$ & $\begin{array}{l}\text { 18. Ebéd elótt veszi észre, hogy elfelejtette a reggeli elött bevinni az inzulinadag- } \\
\text { ját. Mit kell tennie most? }\end{array}$ \\
\hline b. Bármilyen olyan étel, amely címkéjén az szerepel, hogy „zsírmentes” & a. Kihagyni az ebédet, hogy lejjebb vigye a vércukorszintjét \\
\hline c. Bármilyen cukormentes étel & b. Azt a mennyiségú inuzlint bevinni, amelyet általában reggeli előtt szokott \\
\hline \multirow{2}{*}{$\begin{array}{l}\text { d. Bármilyen olyan étel, amelyben kevesebb mint } 20 \text { kalória van } \\
\text { adagonként* }\end{array}$} & c. A reggeli mennyiség kétszeresét kellene bevinnie \\
\hline & d. Ellenőrizni kell a vércukorszintjét, hogy eldöntse, mennyi inzulint vigyen be* \\
\hline 5. A HbAlc az átlagos vércukorszint értéke az elmúlt: & 19. Ha kezdeti alacsonyvércukorszint-reakciót észlel magán: \\
\hline a. 1 napra vonatkozóan & a. testmozgást kell végeznie \\
\hline b. 1 hétre vonatkozóan & b. le kell feküdnie és pihennie kell \\
\hline c. 6-12 hétre vonatkozóan* & c. gyümölcslevet kell innia* \\
\hline d. 6 hónapra vonatkozóan & d. gyorsan ható inzulint kell bevinnie \\
\hline 6. Mi a legjobb módja az otthoni vércukorszintmérésnek? & 20. Alacsonyvércukorszint-reakciót okozhat: \\
\hline a. Vizeletvizsgálat & a. túl sok inzulin* \\
\hline b. Vérvizsgálat* & b. túl kevés inzulin \\
\hline \multirow[t]{2}{*}{ c. Mindkettő egyformán jó } & c. túl sok étel \\
\hline & d. túl kevés testmozgás \\
\hline $\begin{array}{l}\text { 7. Milyen hatása van az édesités nélküli gyümölcslének a vércukorszintre? } \\
\text { a. Csökkenti }\end{array}$ & $\begin{array}{l}\text { 21. Ha beviszi a reggeli inzulinadagját, de kibagyja a reggelit, a vércukorszint- } \\
\text { je általában: }\end{array}$ \\
\hline b. Növeli* & a. emelkedni fog \\
\hline \multirow[t]{2}{*}{ c. Nincs hatása } & b. csökkenni fog* \\
\hline & c. ugyanannyi marad \\
\hline 8. Melyik nem alkalmazható alacsony vércukorszint kezelésére? & 22. Mindenképpen magas vércukorszintet okoz: \\
\hline a. 3 szem kemény cukorka & a. a nem elegendő inzulin* \\
\hline b. $1 / 2$ pohár narancslé & b. az étkezések kihagyása \\
\hline c. 1 pohár diétás üdítőital* & c. az uzsonna késleltetése \\
\hline d. 1 pohár sovány tej & d. a testmozgás kihagyása \\
\hline $\begin{array}{l}\text { 9. Milyen hatása van a testmozgásnak a vércukorszintre egy jó egészségi } \\
\text { állapotban levó személynél? }\end{array}$ & $\begin{array}{l}\text { 23. Alacsonyvércukorszint-reakciót okozhat: } \\
\text { a. fokozott testmozgás* }\end{array}$ \\
\hline a. Csökkenti* & b. fertőzés \\
\hline b. Növeli & c. túlevés \\
\hline c. Nincs hatása & d. ha nem veszi be az inzulinadagját \\
\hline
\end{tabular}

c. Nincs hatása

10. A legtöbb fertözö betegség okozhat:

a. vércukorszint-emelkedést*

b. vércukorszint-csökkenést

c. változatlan vércukorszintet

11. A lábápolás legjobb módja:

a. naponta átnézni és megmosni őket*

b. naponta átmasszírozni alkohollal

c. napi egyórás áztatás

d. a szokásosnál eggyel nagyobb méretü cipő vásárlása

12. A csökkentett zsirtartalmú ételek fogyasztása csökkenti az esélyét:

a. az idegrendszeri betegségek kialakulásának

b. a vesebetegségek kialakulásának

c. a szívbetegségek kialakulásának*

d. a szembetegségek kialakulásának

13. Minek a tünete lehet a zsibbadás és bizsergés?

a. Vesebetegségnek

b. Idegrendszeri betegségnek*

c. Szembetegségeknek

d. Májbetegségnek

14. Az alábbiak közül melyik nem kapcsolódik a cukorbetegséghez?

a. Látási problémák

b. Veseproblémák

c. Idegrendszeri problémák

d. Tüdőproblémák*

HbAlc $=$ hemoglobin-A-1c 
A magyar nyelvú Diabetes Betegségismeret Teszt (DKT2) egye kérdéseire adott helyes válaszok aránya

\begin{tabular}{|c|c|}
\hline A DKT2-kérdések sorszáma & A helyesen válaszolók száma (\%) \\
\hline \multicolumn{2}{|l|}{ Általános kérdések } \\
\hline DKT2_1. & $104(80,6)$ \\
\hline DKT2_2. & $82(63,6)$ \\
\hline DKT2_3. & $95(73,6)$ \\
\hline DKT2_4. & $70(54,3)$ \\
\hline DKT2_5. & $102(79,1)$ \\
\hline DKT2_6. & $125(96,9)$ \\
\hline DKT2_7. & $107(82,9)$ \\
\hline DKT2_8. & $93(72,1)$ \\
\hline DKT2_9. & $113(87,6)$ \\
\hline DKT2_10. & $108(83,7)$ \\
\hline DKT2_11. & $118(91,5)$ \\
\hline DKT2_12. & $117(90,7)$ \\
\hline DKT2_13. & $123(95,3)$ \\
\hline DKT2_14. & $127(98,4)$ \\
\hline \multicolumn{2}{|l|}{ Inzulinhasználati kérdések } \\
\hline DKT2_15. & $34(26,4)$ \\
\hline DKT2_16. & $122(94,6)$ \\
\hline DKT2_17. & $115(89,1)$ \\
\hline DKT2_18. & $121(93,8)$ \\
\hline DKT2_19. & $113(87,6)$ \\
\hline DKT2_20. & $110(85,3)$ \\
\hline DKT2_21. & $113(87,6)$ \\
\hline DKT2_22. & $106(82,2)$ \\
\hline DKT2_23. & $105(81,4)$ \\
\hline
\end{tabular}

A teljes teszt helyes kitöltési arányának átlaga: 81,66\%

Az általános tudástételek helyes kitöltési arányának átlaga: 82,16\%

Az inzulinspecifikus tudástételek helyes kitöltési arányának átlaga: $80,89 \%$

Screen-nel (BHLS [19], magyarul [20]) összefüggéseiben.

A DKT2-kérdőív - ahogy fentebb részletesen bemutattuk - egy 23 kérdésből álló tudásteszt diabetesesek betegség- és betegséggondozásának mérésére. A kérdésekre előre megadott tételek közül kell válaszolni, minden esetben 1 helyes válasz van. Ezek összege adja a teszt pontértékét: a magasabb pontszám nagyobb tudást jelent a betegségről [16]. Az angol nyelvü teszt magyarra fordításakor Gudmundsson [21] ajánlásait követtük: két független, mindkét nyelvet magas szinten beszélő, hozzáértő személy lefordította a teszteket angolról magyar nyelvre. Közös egyeztetés után létrehoztak egy egységes magyar verziót. A felmerülő kérdésekről jegyzőkönyv készült. A két változat, a jegyzőkönyv és Fitzgerald és mtsai [16] ajánlásai alapján a jelen tanulmány szerzőit tartalmazó szakértői csoport alakított ki egy előzetes változatot. Ezzel 2018. január és július között 89 fó részvételével pilotvizsgálatot végeztünk, melyben teszteltük a kérdések értelmezhetőségét is. Összességében a kérdőív 4 tételén módosítottunk: Fitzgerald és mtsai [16] ajánlása szerint (nem amerikai mintán javasolt az 1., 2., 3., 4. és 8. tétel felülvizsgálata kulturális szempontból) az ételek ismertségének figyelembevételével a 2. tételben svájci sajt helyett ementáli sajt, mogyoróvaj helyett pedig mogyorókrém szerepel, a 3 . tételben $2 \%$-os helyett 1,5\%-os tejzsírtartalom, míg kukorica helyett tarkabab. A tételek módosításakor ellenőriztük a válaszok helyességét is az új választási lehetőségekkel, ami a 2. tételnél megváltoztatta a helyes választ. A betegek visszajelzései alapján a 10 . és a 22. tételre több jó válasz is adható volt - ezek esetében diabetológus szakorvossal konzultáltunk az egyértelmúsítés előtt. Így a 10. tételbe „A fertőzés okozhat” helyett „A legtöbb fertőző betegség okozhat” kezdő mondat került, a 22.-be pedig a „Magas vércukorszintet okozhat” helyett a „Mindenképpen magas vércukorszintet okoz".

A BHLS-kérdéseket [19] az egészségértés önbevalláson alapuló, a klinikumban alkalmazható gyors előszűrésére fejlesztették ki, ezért minél magasabb pontszámot ér el valaki az egyes válaszok pontértékeinek összeadása után, annál problémásabb egészségmúveltségrôl beszélhetünk. A 3 tétel pontozása 5 fokozatú Likert-skálán történik, amelyen $0=$ Soba, 1 = Kevésszer, $2=$ Néha, $3=$ A legtöbbször és 4 = Mindig. Az eredeti pontozás szerint az első tételre adott pontérték számítása fordított.

\section{Eljárás}

A kérdőívcsomag kitöltése nagyrészt online zajlott 2019. november és 2020. augusztus között. A tesztek kitöltése egy személy esetében körülbelül 30 percet vett igénybe. A betegtájékoztató megismerése után egyetértés esetén a páciensek aláírták a beteg-beleegyező nyilatkozatot (az online kérdőívkitöltéskor az elfogadást egy pipa bekattintásával jelezték). Az adatgyüjtést az SZTE ÁOK Egészséggazdaságtani Intézetének számítógépén, a Survio nevű szoftverrel (Brno, Csehország) végeztük.

\section{Eredmények}

A célteszt megbízhatóságának, szociodemográfiai változókkal való összefüggéseinek és konvergens validitásának megállapítására az SPSS statisztikai programcsomag 22es verzióját (IBM Corporation, Armonk, NY, Amerikai Egyesült Államok) használtuk. Statisztikailag szignifikáns eltérésnek a $<0,05$ p-értéket fogadtuk el.

\section{Leiró statisztika: a tesztek megbizhatósága, az egyes tételek helyes kitöltési arányai}

A DKT2 23 kérdésének konzisztenciája (Cronbach- $\alpha-$ értéke) 0,603, amely elfogadható érték. Mivel inzulint használó cukorbetegekkel validáltuk a tesztet, nem vizsgáltuk külön az első 14 általános és a 9 inzulinhasználati 
kérdés megbízhatóságát, az átlag- és szórásértékeket azonban mindhárom esetben megadjuk: $\mathrm{M}_{23}=18,78$ $(\mathrm{SD}=0,23) ; \mathrm{M}_{14}=11,5(\mathrm{SD}=0,14)$ és $\mathrm{M}_{9}=7,28(\mathrm{SD}=$ $0,12)$.

A mintában a teszteredmények nem követik a normáleloszlást (Kolmogorov-Szmirnov-érték a 23 tételre: 0,208), így a továbbiakban nemparaméteres statisztikai próbákat használtunk a számításokhoz. Az általános és az inzulinhasználatra vonatkozó tesztrészek közötti korreláció 0,392 volt $\left(\rho_{127}=0,392 ; p<0,000\right)$, ami szignifikáns, gyenge, pozitív együttjárásnak számít. Az egyes tesztrészek szignifikáns, erôs, pozitív korrelációt mutattak az összpontszámmal ( $\mathrm{DKT}_{14}$ és 23 között $\rho_{127}=0,873$; $\mathrm{p}<0,000 ; \mathrm{DKT}_{9}$ és 23 között $\left.\rho_{127}=0,766 ; \mathrm{p}<0,000\right)$.

Az 1. táblázat foglalja össze, hogy a minta hány százaléka válaszolt helyesen az egyes kérdésekre. A teljes teszt helyes kitöltési arányának átlaga 81,66\%, ehhez közeli átlagot mértünk az általános tudástételek $(82,16 \%)$ és az inzulinspecifikus tudástételek $(80,89 \%)$ esetében is. Az arányok alapján az látszik, hogy a betegek az általános kérdések közül a legnehezebbnek az egyes ételek tápanyag-összetevőinek, valamint az elfogyasztott ételek vércukorszintre gyakorolt hatásának a megítélését tartották, a legkönnyebbnek pedig a szövődmények tüneteinek felismerését. Az inzulinspecifikus kérdéseknél a mindennapi tevékenységek következményeként fellépó inzulinváltozás irányát minden esetben $80 \%$ felett válaszolták meg helyesen a betegek, kiugró érték a ketoacidosis-fogalom ismeretének hiánya miatt jelentkezett.

Zowgar és mtsai [18] felosztása alapján meghatároztuk mintánkban az alacsony $(2,3 \%)$, átlagos $(30,2 \%)$ és magas $(67,4 \%)$ betegségismerettel rendelkezők arányát. Mintánkban a leggyakoribb a magas betegségismeret volt.

A konvergens validálás ellenórzéséhez önbevalláson alapuló, magyar sztenderd értékekkel rendelkező egészségértéstesztet alkalmaztunk, a BHLS-t. A teszt belsó konzisztenciája a mintánkon 0,719 volt, ami kiváló megbízhatóságra utal. A DKT2-összpontszámmal szignifikáns, gyenge, negatív együttjárást mutat $\left(\rho_{127}=-0,246\right.$; $\mathrm{p}<0,005)$. A negatív korreláció oka, hogy a BHLS-en minél magasabb értéket kap egy személy, annál problémásabb az egészségmúveltsége.

\section{A DKT2-teszt összefüggése a demográfiai és betegségváltozókkal}

A szakirodalomnak megfelelően a szociodemográfiai változók közül a nemmel, az iskolai végzettséggel, az életkorral és a betegségre fordított jövedelem mértékével vetettük össze a betegségismeretet. A betegségváltozók közül a diagnózis óta eltelt évek számának, az inzulinhasználat idejének (év), a kezelés típusának (inzulin vagy inzulin és tabletta), a szövődmények számának, a napi inzulinbeadás és a vércukorszintmérés számának összefüggéseiben vizsgáltuk a DKT2-kérdőívet. A gyakorlat szempontjából az egészségügyi kimenetelek közül a szubjektív egészségi állapotra gyakorolt jóslóértékét teszteltük.

A szociodemográfiai változók közül a DKT2 összpontszáma az életkorral szignifikáns, gyenge, negatív összefüggésben áll $\left(\rho_{127}=-0,194, p=0,028\right)$, a nemmel, az iskolai végzettséggel és a betegségre költött jövedelemmel azonban nincs kapcsolatban. A betegségváltozók közül a DKT2 az inzulinhasználat idejével, valamint a napi vércukorszintmérés és inzulinbeadás számával mutatott szignifikáns pozitív korrelációt $\left(\rho_{127}=0,174, \mathrm{p}=\right.$ 0,$\left.048 ; \rho_{127}=0,444, p<0,000 ; \rho_{127}=0,217, p=0,014\right)$. A DKT2-összpontszámmal együtt járó változók hatását lineáris regressziós elemzéssel is teszteltük ('Enter' módszer), melyben a modell szignifikáns lett $\left(\mathrm{F}_{4}=8,92\right.$; $\mathrm{p}<0,000)$, a variancia $22,3 \%$-át magyarázta, a többi változótól függetlenül azonban csak a napi vércukorszintmérés száma jósolta be a betegségismeret mértékét ( $\beta=$ $0,37, \mathrm{t}=3,58, \mathrm{p}<0,000)$. A mért szövődmények közül a betegségismeret egyedül a szív- és érrendszeri problémák jelenlétével függött össze szignifikánsan: alacsonyabb összpontszám $(M=18 S D=3,12$ vs. $M=19,1$ $\left.\mathrm{SD}=2,31, \mathrm{t}_{127}=2,2, \mathrm{p}=0,03\right)$ jellemezte azokat a cukorbetegeket, akiknél megjelent ez a szövődménytípus.

A DKT2 nem függött össze a szubjektív egészségi állapottal, a BHLS azonban igen $\left(\rho_{127}=-0,277, \mathrm{p}=0,02\right)$ : a problémásabb szubjektív egészségértés rosszabb szubjektív egészségi állapottal járt együtt.

\section{Megbeszélés}

Tanulmányunk célja a DKT2-teszt magyar nyelvú validálása volt. A teszt belső konzisztenciája inzulint használó, 2 -es típusú cukorbetegeknél 0,603 volt, ami elfogadható érték. Fitzgerald 1998-ban és 2016-ban [15, 16] 0,7 feletti értékekról számolt be, azonban a 23 kérdésre együtt nem adott meg Cronbach- $\alpha$-értéket, a michigani egyetemi klinika diabetes-nyilvántartásában szereplő mintán pedig 0,5 alatti értékeket kapott. Ez arra is felhívja a figyelmet, hogy a DKT2 megbízhatóságát érdemes külön ellenőrizni 1-es és 2-es típusú diabeteses minta esetén.

A 23 kérdés helyes kitöltési arányának átlaga kutatásunkban $81,66 \%$, ami az amerikai arányokhoz hasonló (általános teszt: 77\%, inzulinalskála: 73\% [16]), más kutatásokban vizsgált speciális csoportokhoz képest azonban kifejezetten magas értéknek számít (például amerikai veteránoknál 64,6\% [22]). Mintánk magas tudásszintjét mutatja Zowgar és mtsai [18] tudásövezet szerinti felosztásának alkalmazása is. Míg kutatásunkban a betegek 2,3\%-a tartozott az alacsony, 30,2\%-a az átlagos és 67,4\%-a a magas tudásövezetbe, arab mintán ez az arány sorrendben $29,2 \%, 66,1 \%$ és $4,7 \%$, bengálin pedig 18\%, 66\% és 16\% volt [23]. A különbségek adódhatnak a minták eltéréseiből, az adatgyưjtés módjából (mi elsősorban országos betegszervezeten keresztül online toboroztunk) és az adott ország diabetesoktatásának jellegzetességeiból is. Az a következtetés levonható, hogy a magyar tudásszint a DKT2-teszten átlagos vagy annál 
magasabb, ami a több mint két évtizede bevezetett „diabetológiai szakápoló és edukátor” posztgraduális képzés eredményességét tükrözheti.

Az orvosi gyakorlatban fontos kérdés, hogy melyek voltak azok az itemek, amelyekre a legkevésbé tudták a választ a betegek. A ketoacidosis fogalma egyértelmüen ilyen tétel, ezenkívül, ahogy fentebb kiemeltük, a betegek a legkevésbé az egyes ételek tápanyag-összetevőit (szénhidráttartalom, zsírtartalom), valamint az elfogyasztott ételek vércukorszintre gyakorolt hatását ismerték. Az előbbi hiányosság az arab mintában is megjelent a 2. és 3. tételnél, és felhívja a figyelmet a betegek diétára vonatkozó magasabb szintű tudásának szükségességére. A cukorbetegek diétájának önmenedzselését segítő applikációk áttekintésekor Szálka és mtsai [24] is arra mutatnak rá, hogy azok az alkalmazások hasznosak, amelyek a szénhidrátok mennyiségének összegzésén túl azok vércukorszint-emelő hatásáról is informálnak.

A szakirodalomban egyértelmú az önbevalláson alapuló, illetve a funkcionális egészségértés összefüggése a betegségismerettel ([9] metaelemzése). Kutatásunk eredménye is ezt mutatja a BHLS és a DKT2 között, vagyis akinek nagyobb tudása van betegségéről, az magabiztosabb az egészségügyi kérdésekben való eligazodásban. A két változó közötti kapcsolat erôssége ugyanakkor alátámasztja az eltérő egészségértési formák létezését is.

A szociodemográfiai változók közül a magyar DKT2 a szakirodalomnak megfelelő gyenge, negatív irányú összefüggésben áll az életkorral $[10,18]$, nincs kapcsolatban azonban a nemmel, az iskolai végzettséggel és a betegségre költött jövedelemmel. A nemzetközi szakirodalom ellentmondásos eredményeket közöl az általános egészségmúveltség nemi különbségeinek tekintetében. Magyar mintán korábban nem találtunk különbséget a nemek között [20], így nem meglepő, hogy ez a mostani, diabeteses mintában sem jelent meg. Konzisztensebb a kapcsolat a magasabb jövedelem és a jobb egészségértés között mind általános mintán [20], mind diabetesesek körében [17]. Kutatásunkban az összefüggés hiánya eredhet abból, hogy nem az összjövedelem megbecsülését kértük, hanem a betegségre fordított részét. A magasabb kiadások súlyosabb állapotra és így rosszabb egészségértésre utalhatnak - ezt a BHLS-sel kapott tendenciaszintű, pozitív kapcsolat mutatja.

A szociodemográfiai változók közül visszatérő, robusztus összefüggést minden típusú egészségértéssel az iskolai végzettség mutat (általános, magyar mintán [20]; a cukorbetegség ismeretét felmérő teszten [16-18, 25]), így ennek hiánya a DKT2-vel kutatásunkban magyarázatot kíván. Felvethető, hogy az inzulinnal kezelt cukorbetegek Magyarországon megfelelő betegoktatásban részesülnek, ami kiegyenlíti az iskolázottságból adódó alapvető betegségismeretük szintjei közti különbséget.

A betegségváltozók közül a DKT2 az inzulinhasználat hosszával, valamint a napi vércukorszintmérés és inzulinbeadás számával mutatott pozitív kapcsolatot - melyek a szakirodalommal [17, 18] megegyező eredmények.
Ezek közül a betegségismeretet függetlenül egyedül a napi vércukorszintmérés mennyisége jósolta be. A szakirodalomnak ellentmondóan nem volt összefüggés a kezelés típusával [16], a cukorbetegség időtartamával [17, 18] és a szövődmények számával sem [9, 26]. Egyetlen szövődménytípus képezett kivételt: azoknál a cukorbetegeknél, akiknél megjelentek szív- és érrendszeri szövődmények, szignifikánsan alacsonyabb betegségismeretet mértünk. Ezek magyarázatában ismét utalnánk mintánk speciális jellegére: az inzulint használó, 2-es típusú cukorbetegek jellemzően hosszabb ideje élnek együtt a betegséggel, tudás szempontjából az egyik legerősebb csoportot képezik. A szövődmények tüneteinek felismerése a legmagasabb helyes válaszarányú volt a kutatásban, ami oka lehet annak, hogy miért nincs különbség a szövődmények száma mentén a tudásszintben.

A szakirodalom szerint az egészségértés alacsony szintje negatívan befolyásolja az egészségi állapotot [27, 28], kutatásunkban azonban ezt az összefüggést csak a BHLS esetén kaptuk meg. Ennek okát az alkalmazott tesztek típusában is kereshetjük: az önbevalláson alapulók egyfajta attitüdöt, hatékonyságérzetet is mérhetnek, míg a DKT2 objektív eredményt ad. A teszttel folytatott jövőbeli kutatásoknak érdemes az egészségügyi állapot objektívabb változóit is felhasználniuk az egészségértés következményeinek felmérésében.

\section{Következtetés}

A magyar nyelvű Diabetes Betegségismeret Teszt alkalmas a diabetesszel élők tudásszintjének felmérésére. Mintánkban a betegségismeret szintje átlagos vagy annál magasabb, ami mintánk jellegével (inzulint használó, 2-es típusú cukorbetegek) és az inzulint használók megfelelő hazai edukációjával függhet össze. Ugyanakkor eredményeink felhívják a figyelmet a betegek diétára vonatkozó magasabb szintű tudásának szükségességére.

Anyagi támogatás: A kézirat elkészítéséhez kapcsolódó kutatómunka az EFOP-3.6.1-16-2016-00008. számú alprojekt keretében anyagi támogatásban részesült.

Szerzôi munkamegosztás: P.-Z. O.: A tesztbattéria kérdőíveinek kiválasztásában való részvétel és annak koordinálása, a fordítási munka végzése, a tesztfelvétel betanítása és az adatfelvételben való részvétel, adatelemzés, valamint a kézirat megszövegezése. K. A.: A tesztanyag kérdőíveinek kiválasztásában és az adatfelvételben való részvétel és a kézirat szövegének javítása. B. N.: A tesztanyag kérdőíveinek kiválasztásában való részvétel, a fordítási munka végső jóváhagyása, a kutatás menetének felügyelése, valamint a kézirat szövegének javítása. A cikk végleges változatát valamennyi szerző elolvasta és jóváhagyta.

Érdekeltségek: A szerzőknek nincsenek érdekeltségeik. 


\section{Köszönetnyilvánítás}

Köszönetet mondunk az adatfelvételt lehetővé tevő betegszervezeteknek, valamint az intézmények vezetőinek, a részt vevő betanított hallgatóknak, a tesztbattériát kitöltőknek, dr. Martos Tamásnak a statisztikai elemzésben nyújtott tanácsaiért, valamint $d r$. Lengyel Csabának a diabetológiai szakkérdések megvitatásáért.

\section{Irodalom}

[1] International Diabetes Federation. IDF Diabetes Atlas, 9th edition 2019. Available from: www.idf.org/diabetesatlas [accessed: April 18, 2020].

[2] Turk E, Palfy M, Prevolnik Rupel V, et al. General knowledge about diabetes in the elderly diabetic population in Slovenia. Zdrav Vestn. 2012; 81: 517-525.

[3] Al-Qazaz HK, Hassali MA, Shafie AA, et al. The 14-item Michigan Diabetes Knowledge Test: translation and validation study of the Malaysian version. Pract Diabetes 2010; 27: 238-242.

[4] Ratzan SC, Parker RM. Introduction. In: Selden CR, Zorn M, Ratzan S. (eds.) National Library of Medicine. Current bibliographies in medicine: health literacy. National Institutes of Health, U.S. Department of Health and Human Services, Bethesda, MD, 2000; pp. v-vi.

[5] Baker DW, Wolf MS, Feinglass J, et al. Health literacy and mortality among elderly persons. Arch Intern Med. 2007; 167: 1503-1509.

[6] Wolf MS, Davis TC, Osborn CY, et al. Literacy, self-efficacy, and HIV medication adherence. Patient Educ Couns. 2007; 65: 253-260.

[7] Schillinger D, Piette J, Grumbach K, et al. Closing the loop: physician communication with diabetic patients who have low health literacy. Arch Intern Med. 2003; 163: 83-90.

[8] Fransen MP, von Wagner C, Essink-Bot ML. Diabetes self-management in patients with low health literacy: ordering findings from literature in a health literacy framework. Patient Educ Couns. 2012; 88: 44-53.

[9] Al Sayah F, Williams B, Johnson JA. Measuring health literacy in individuals with diabetes: a systematic review and evaluation of available measures. Health Educ Behav. 2013; 40: 42-55.

[10] Dunn SM, Bryson JM, Hoskins PL, et al. Development of the Diabetes Knowledge (DKN) scales: forms DKNA, DKNB, and DKNC. Diabetes Care 1984; 7: 36-41

[11] Osborn CY, Cavanaugh K, Wallston KA, et al. Self-efficacy links health literacy and numeracy to glycemic control. J Health Commun. 2010; 15(Suppl 2): 146-158.

[12] Gherman A, Schnur J, Montgomery G, et al. How are adherent people more likely to think? A meta-analysis of health beliefs and diabetes self-care. Diabetes Educ. 2011; 37: 392-408.

[13] Hess GE, Davis WK. The validation of a Diabetes Patient Knowledge Test. Diabetes Care 1983; 6: 591-596.

[14] Munkácsi B, Nagy BE, Kovács KE. Investigation of the adherence of children with diabetes through the validation of the child version of the Diabetes Adherence Questionnaire. [Cukorbeteg gyermekek együttmúködésének vizsgálata a Diabetes Adherencia Kérdőív gyermekváltozatának validálása során.] Orv Hetil. 2019; 160: 1136-1142. [Hungarian]

[15] Fitzgerald JT, Funnell MM, Hess GE, et al. The reliability and validity of a brief diabetes knowledge test. Diabetes Care 1998; 21: 706-710.

[16] Fitzgerald JT, Funnell MM, Anderson RM, et al. Validation of the revised brief Diabetes Knowledge Test (DKT2). Diabetes Educ. 2016; 42: 178-187.

[17] Al-Adsani AM, Moussa MA, Al-Jasem LI, et al. The level and determinants of diabetes knowledge in Kuwaiti adults with type 2 diabetes. Diabetes Metab. 2009; 35: 121-128.

[18] Zowgar AM, Siddiqui MI, Alattas KM. Level of diabetes knowledge among adult patients with diabetes using diabetes knowledge test. Saudi Med J. 2018; 39: 161-168.

[19] Chew LD, Griffin JM, Partin MR, et al. Validation of screening questions for limited health literacy in a large VA outpatient population. J Gen Intern Med. 2008; 23: 561-566.

[20] Papp-Zipernovszky O, Náfrádi L, Schulz PJ, et al. "So each patient comprehends": measuring health literacy in Hungary. [„Hogy minden beteg megértse!” - Az egészségmúveltség (health literacy) mérése Magyarországon.] Orv Hetil. 2016; 157: 905-915. [Hungarian]

[21] Gudmunsson E. Guidelines for translating and adapting psychological instruments. Nord Psychol. 2009; 61: 29-45.

[22] Murata GH, Shah JH, Adam KD, et al. Factors affecting diabetes knowledge in type 2 diabetic veterans. Diabetologia 2003; 46: 1170-1178.

[23] Saleh F, Mumu SJ, Ara F, et al. Knowledge and self-care practices regarding diabetes among newly diagnosed type 2 diabetics in Bangladesh: a cross-sectional study. BMC Public Health 2012; 12: 1112 .

[24] Szálka B, Kósa I, Vassányi I, et al. Support of diabetes dietary management and self-management using mobile applications. [Diabetesesek dietoterápiájának és önmenedzselésének támogatása mobilapplikációk használatával.] Orv Hetil. 2016; 157: 1147-1153. [Hungarian]

[25] $\mathrm{Hu}$ J, Gruber KJ, Liu H, et al. Diabetes knowledge among older adults with diabetes in Beijing, China. J Clin Nurs. 2013; 22: 51-60.

[26] Anbarasan S, Anil G, Srinivaasan M, et al. Level of health literacy among type 2 diabetic persons and its relation to glycemic control. J Assoc Physicians India 2019; 67: 59-62.

[27] Ivanisic M. Testing health literacy in Osijek hospital patients using the validated Croatian version of Newest Vital Sign (NVS) health literacy instrument. PLoS ONE 2018; 13: 1-14.

[28] Ubavić S, Krajnović D, Marinković V. Analysis of health literacy instruments which could be used on a primary healthcare level. Arch Pharm Res. 2015; 65: 72-87.

(Papp-Zipernovszky Orsolya dr., Szeged, Egyetem u. 2., 6722 e-mail: papp.orsolya@psy.u-szeged.hu)

A cikk a Creative Commons Attribution 4.0 International License (https://creativecommons.org/licenses/by/4.0/) feltételei szerint publikált Open Access közlemény, melynek szellemében a cikk bármilyen médiumban szabadon felhasználható, megosztható és újraközölhetö, feltéve, hogy az eredeti szerző és a közlés helye, illetve a CC License linkje és az esetlegesen végrehajtott módosítások feltüntetésre kerülnek. (SID_1) 